CLINICAL STUDY

\title{
Impaired puberty, fertility, and final stature in 45,X/46,XY mixed gonadal dysgenetic patients raised as boys
}

Laetitia Martinerie, Yves Morel ${ }^{1}$, Claire-Lise Gay ${ }^{2}$, Catherine Pienkowski ${ }^{3}$, Marc de Kerdanet $^{4}$, Sylvie Cabrol ${ }^{5}$, Claudine Lecointre $^{6}$, Regis Coutant ${ }^{7}$, Sabine Baron ${ }^{8}$, Michel Colle ${ }^{9}$, Raja Brauner ${ }^{10}$, Elisabeth Thibaud ${ }^{11}$, Juliane Leger $^{12}$, Claire Nihoul-Fekete ${ }^{13}$ and Claire Bouvattier

Pediatric Endocrinology Department, Bicêtre Hospital, 78 Rue du Général Leclerc, 94275 Le Kremlin Bicêtre, France, ${ }^{1}$ Molecular Endocrinology Department, East Centre of Biology and Pathology, Lyon Bron, France, ${ }^{2}$ Pediatric Endocrinology Department, Femme-Mère-Enfant Hospital, Lyon Bron, France, ${ }^{3}$ Pediatric Department, Children Hospital, Toulouse, France, ${ }^{4}$ Pediatric Department, South Hospital, Rennes, France, ${ }^{5}$ Pediatric Endocrinology Department, Trousseau Hospital, Paris, France, ${ }^{6}$ Pediatric Department, Charles Nicolle Hospital, Rouen, France, ${ }^{7}$ Pediatric Department, CHU Angers, Angers, France, ${ }^{8}$ Pediatric Department, Mother and Child Hospital, Nantes, France, ${ }^{9}$ Pediatric Department, CHU Bordeaux, Bordeaux, France, ${ }^{10}$ Pediatric Endocrinology Department, Bicêtre Hospital, Paris-Descartes University, Le Kremlin Bicêtre, France, ${ }^{11}$ Pediatric Endocrinology Department, Necker Hospital, Paris, France, ${ }^{12}$ Pediatric Endocrinology Department, Robert Debre Hospital, Paris, France and ${ }^{13}$ Pediatric Surgery Department, Necker Hospital, Paris, France

(Correspondence should be addressed to C Bouvattier; Email: claire.bouvattier@bct.aphp.fr)

\begin{abstract}
Context: Gender assignment followed by surgery and hormonal therapy is a difficult decision in the management of $45, \mathrm{X} / 46, \mathrm{XY}$ patients with abnormal external genitalia at birth considering the paucity of studies evaluating pubertal development and fertility outcome, most notably for patients raised as boys.

Objective: The purpose of this study was to describe the pubertal course of $2045, \mathrm{X} / 46$,XY patients born with ambiguous genitalia and raised as boys.

Methods: This is a multicenter retrospective study.

Results: Mean age at study was $25.6 \pm 2.4$ years. Eighty-five percent of the patients presented a 'classical' mixed gonadal dysgenetic phenotype at birth. Puberty was initially spontaneous in all but three boys, although in six other patients, testosterone therapy was subsequently necessary for completion of puberty. Sixty-seven percent of the remaining patients presented signs of declined testicular function at the end of puberty (increased levels of FSH and low levels of testosterone and/or inhibin B). Moreover, an abnormal structure of the Y chromosome, known to alter fertility, was found in 10 out of $16(63 \%)$ patients. Two patients developed testicular cancer. Half of the patients have adult penile length of $<80 \mathrm{~mm}$. Mean adult height is $156.9 \pm 2 \mathrm{~cm}$, regardless of GH treatment.

Conclusions: In summary, 45,X/46,XY children born with ambiguous genitalia and raised as boys have an altered pubertal course and impaired fertility associated with adult short stature, which should, therefore, be taken into consideration for the management of these patients.
\end{abstract}

European Journal of Endocrinology 166 687-694

\section{Introduction}

Disorders of sex development (DSD) leading to ambiguous genitalia at birth question the decision of gender assignment. Some of these medical conditions are well known and studied as congenital adrenal hyperplasia (1) or incomplete androgen insensitivity syndrome (2, 3). Conversely, 45,X/46,XY mixed gonadal dysgenesis (MGD) is less characterized. Patients with a $45, \mathrm{X} / 46, \mathrm{XY}$ karyotype, detected in 1.7/10 000 newborns (4), can present various phenotypes, including females with Turner's syndrome (TS) phenotype, newborns with ambiguous genitalia, usually called MGD (4), and normal male development $(5,6,7,8,9,10)$. Gender assignment followed by surgery and hormonal therapy is difficult in the management of $45, \mathrm{X} / 46, \mathrm{XY}$ patients with abnormal external genitalia at birth. Pediatric endocrinologists and surgeons usually recommend raising these patients as boys considering that the unilateral scrotal testis might have potential for testosterone secretion, penile growth, and pubertal development and might preserve reproductive ability (8). However, there is a lack of consistent published data concerning the pubertal development and outcome of these patients $(7,11)$. Thus, the purpose of this study was to describe the pubertal course of $2045, \mathrm{X} / 46, \mathrm{XY}$ patients born with ambiguous genitalia and raised as boys.

This DSD relies on a chromosome missegregation, occurring during early embryonic mitosis, through anaphase lag or interchromosomal rearrangement that induces the emergence of two or three different cell 
lines: 45,X/46,XY and 47,XYY, the latter being often lost after further divisions. It arises de novo and its origin is currently unknown but could be favored by an abnormal structure of the $\mathrm{Y}$ chromosome. Indeed, structural rearrangement of the $\mathrm{Y}$ chromosome (isochromosome, ring chromosome, deletion, etc.) has been described in $45, \mathrm{X} / 46, \mathrm{XY}$ mosaicism (12). It is also encountered in $1 \%$ of male patients being consulted for infertility in the general population (13). Interestingly, a possible link between Y chromosome rearrangement and disorder of sexual development has been observed $(5,12,14,15,16,17)$. Thus, the frequency of $\mathrm{Y}$ structural rearrangements was also evaluated in our patients.

We demonstrate that $45, \mathrm{X} / 46, \mathrm{XY}$ male patients have an absence or an altered course of their pubertal development associated with a final short stature and an impaired fertility in adulthood. A Y chromosome rearrangement was found in $63 \%$ of the patients.

\section{Subjects and methods}

\section{Patients}

We reviewed the clinical records of 20 boys with MGD and followed up from birth (between 1953 and 1994) to adult stage in the Pediatric and Adult Endocrinology Clinics of seven French hospitals. Inclusion criteria were as follows: a 45,X/46,XY karyotype, ambiguous genitalia at birth, male gender assignment, and ongoing or achieved puberty at the time of inclusion. All the reported cases satisfied the inclusion criteria. This study was approved by the Local Ethics Committee of each center, and informed consent was obtained from all patients.

The following data were collected from their medical files:

- Clinical data: gestational age, birth height, parents' height, description of external and internal genitalia (from clinical reports, ultrasound, cystography, and surgical procedures), age at onset of puberty (defined by testis length $>35 \mathrm{~mm}$ ), pubertal growth, adult height, adult genital phenotype, medical treatments (steroid hormones during infancy and at puberty, $\mathrm{GH}$ : timing and duration of treatment), and surgical procedures (timing and number of procedures).

- Hormonal levels: last testosterone, LH, FSH, AMH, and inhibin B concentrations.

- Gonad histology after gonadectomy or biopsy: histological reports were analyzed for a second time with the help of an expert in gonad histology. Gonads were qualified as dysgenetic testes when seminiferous tubules were associated with an abnormal structure of the tunica albuginea (thin and/or insufficiently developed) and/or a complete absence of germ cells and/or sites of fibrosis. Streak gonads were identified as fibrotic tissue without any germ cells or sexual differentiation (neither seminiferous tubules nor ovarian follicles).

- Cytogenetic analyses and Y chromosome rearrangements: karyotypes were performed on cultured blood lymphocytes arrested in mitosis and stained with Giemsa dye and/or fluorescent in situ hybridization. At least 30 mitoses were examined to determine the degree of mosaicism.

Questionnaires were also given or sent to the patients in order to collect data about quality of life: actual job/scholarship, self-appreciation, relationships, and sexual life, which was categorized as follows: 0, no sexual life; 1 , dissatisfying (occasional and/or painful sexual intercourses); and 2, satisfying (frequent and nonpainful sexual intercourses).

\section{Statistical analyses}

Results are expressed as mean \pm s.e.m. Statistical analyses were performed using a nonparametric Mann-Whitney U-test. Correlations between two parameters were obtained after Spearman regression analysis (Graph Prism, Graphpad Software, Inc., San Diego, CA, USA) with significant threshold at 0.05.

\section{Results}

Twenty patients were included in the study. Mean age at the time of inclusion was $25.6 \pm 2.4(15.3-56)$ years.

\section{Clinical characteristics at birth}

Diagnosis was determined at birth for all except one patient who had been prenatally diagnosed (amniocentesis performed for a short thighbone). Ten out of the 20 $(50 \%)$ patients were born with intrauterine growth retardation (IUGR, defined as a birth height $<10 \%$ of predicted height for gestational age). Seventeen out of the $20(85 \%)$ patients presented a 'classical' mixed gonadal dysgenetic phenotype at birth (Fig. 1A and B, Table 1): hypospadias, vagina, hemiuterus and streak or dysgenetic gonad on one side, and testis with epididymis and deferent duct on the other side. Two patients (nos 15 and 16) presented with hypospadias and two scrotal gonads and one patient (no. 1) presented with posterior (proximal) hypospadias and bilateral cryptorchidism. Mean genital tubercle length was $21.4 \pm 0.7 \mathrm{~mm}$. Sex assignment was decided during the first months of life for all patients.

Fourteen of the $20(70 \%)$ patients developed TS features. Cardiac anomalies were observed in three patients: two of them presented with an aortic coarctation $(10 \%)$. Renal malformations were noted in four patients $(20 \%)$ and mild mental retardation was diagnosed in two patients. 
A

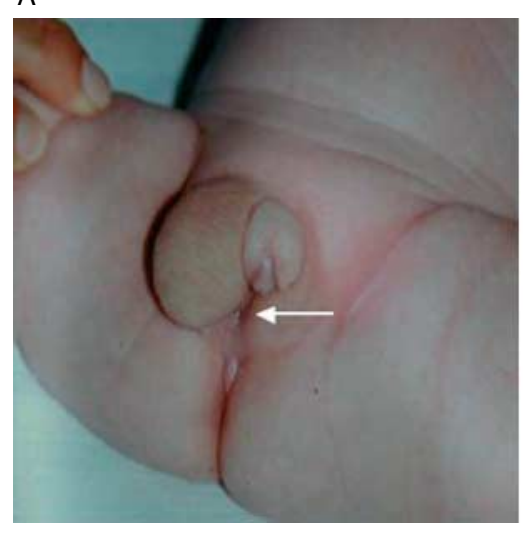

B

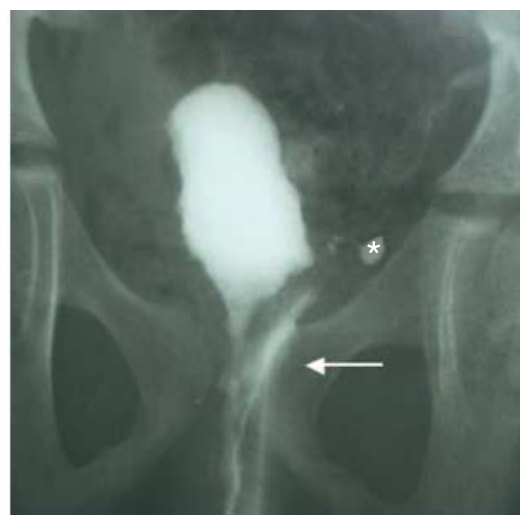

Figure 1 Phenotypic characteristics of external and internal genitalia at birth. (A) Eighty-five percent of the patients had a hemiscrotum containing a gonad on one side and hemi-labia on the other side. All patients had a unique orifice (arrow). (B) Vaginal pocket (arrow): $92 \%$ of the patients had a hemiuterus (asterisk).

\section{Gonads}

Histology The association of a streak gonad and an opposite dysgenetic or infantile testis was seen in 15/19 (79\%) cases (Supplementary Table 1, see section on supplementary data given at the end of this article). One patient (no. 8) had bilateral dysgenetic testes. Three patients (nos 6, 12, and 15) did not have testicular biopsy. No relationship was observed between the histology of the gonads and the degree of genital masculinization or the presence of a uterus.

Tumors No gonadoblastoma was seen. A dysgerminoma (patient no. 1) and a seminoma (patient no. 3) were diagnosed at the age of 13 and 23 years respectively. They had originated from an intra-abdominal streak gonad in the first case and an intrascrotal dysgenetic testis in the second case (inguinal at birth with orchidopexy at the age of 9 years).

\section{Surgical reconstruction and testosterone treatment during infancy}

Testosterone treatment Forty-five percent (9/20) of the patients received a mean dose of $156 \pm 20 \mathrm{mg}$ of i.m. testosterone before the age of 4 years. Mean increase in penile length was $12.6 \pm 2.5 \mathrm{~mm}$ (see Table 2).

Surgery The first surgical procedure was performed at a mean age of $16.6 \pm 4.5$ months, with a mean of $3.6 \pm 0.4$ surgeries for each child. When considered,

Table 1 Patient karyotypes and external genitalia presentation at birth. Posterior hypospadias refers to a proximal hypospadias. Information concerning $Y$ chromosome rearrangement was obtained from the karyotype achieved at birth. These karyotypes were performed on culture lymphocytes, and at least 30 mitoses were examined to determine the proportion of the mosaic.

\begin{tabular}{|c|c|c|c|c|c|c|}
\hline Patient & Karyotype & $\begin{array}{c}45, X \\
\text { cells }(\%)\end{array}$ & $\begin{array}{l}\text { Penile length } \\
\text { (mm/SDS) }\end{array}$ & Hypospadias & Right gonad & Left gonad \\
\hline 1 & $45, X / 46, X Y$ & NA & & Posterior & Abdominal & Abdominal \\
\hline 2 & $45, X / 46, X Y$ & 53 & 25 (at 4 years) $/-2.5$ & Penoscrotal & Abdominal & Scrotal \\
\hline 3 & 45,X/46,X,i(Yp) & 25 & $20 /<-2.5$ & Perineal & Abdominal & Inguinal \\
\hline 4 & $45, \mathrm{X} / 46, \mathrm{X}, \operatorname{idic}(\mathrm{Yq})$ & 19 & & Posterior & Inguinal & Abdominal \\
\hline 5 & $45, \mathrm{X} / 46, \mathrm{XY} / 47, \mathrm{XYY}$ & NA & $20 /<-2.5$ & Coronal & Inguinal & Scrotal $20 \times 10 \mathrm{~mm}$ \\
\hline 6 & $45, \mathrm{X} / 46, \mathrm{X}, \mathrm{del}(\mathrm{Yqh}-)$ & 53 & 20 (at 2 years) $/<-2.5$ & Penile & Scrotal & Inguinal \\
\hline 7 & $45, X / 46, X Y$ & NA & & & & \\
\hline 8 & $45, X / 46, X, i(Y p)$ & 25 & & Scrotal & Scrotal & Abdominal \\
\hline 9 & $45, X / 46, X Y$ & 42 & $20 /<-2.5$ & Perineal & Scrotal $10 \times 10 \mathrm{~mm}$ & Inguinal \\
\hline 10 & $45, X / 46, X, \operatorname{del}(Y q)$ & 91 & $25 /-2.5$ & Penoscrotal & Scrotal $10 \times 20 \mathrm{~mm}$ & Inguinal \\
\hline 11 & $45, X / 47, X Y Y$ & 32 & $20 /<-2.5$ & Penoscrotal & Scrotal $20 \times 15 \mathrm{~mm}$ & Abdominal \\
\hline 12 & $45, \mathrm{X} / 46, \mathrm{X}, \mathrm{r}(\mathrm{Y})$ & NA & 30 (at 5 years) $/-2.5$ & Posterior & Scrotal $15 \times 15 \mathrm{~mm}$ & Inguinal \\
\hline 13 & $45, X / 46, X Y$ & 70 & & Posterior & Scrotal & Inguinal \\
\hline 14 & $45, X / 46, X Y$ & 64 & $20 /<-2.5$ & Penoscrotal & Abdominal & Scrotal \\
\hline 15 & $45, X / 46, X Y$ & 60 & & Perineal & $\begin{array}{l}\text { Both scrotal on the } \\
\text { right side }\end{array}$ & \\
\hline 16 & $45, X / 46, X, \operatorname{del}(Y q)$ & 8 & $20 /<-2.5$ & Penile & Scrotal $10 \times 15 \mathrm{~mm}$ & Scrotal $10 \times 15 \mathrm{~mm}$ \\
\hline 17 & $45, X / 46, X, \operatorname{del}(Y q)$ & 34 & $25 /-2.5$ & Penoscrotal & Scrotal $10 \times 5 \mathrm{~mm}$ & Abdominal \\
\hline 18 & $45, \mathrm{X} / 46, \mathrm{X}, \operatorname{idic}(\mathrm{Y})$ & 75 & & Posterior & Scrotal & Abdominal \\
\hline 19 & $45, X / 46, X Y$ & 6 & $24 /-2.5$ & Penoscrotal & Scrotal $10 \times 15 \mathrm{~mm}$ & Abdominal \\
\hline 20 & $45, \mathrm{X} / 46, \mathrm{X}, \operatorname{del}(\mathrm{Yq})$ & 67 & $20 /<-2.5$ & Penoscrotal & Abdominal & Scrotal $10 \times 10 \mathrm{~mm}$ \\
\hline
\end{tabular}

NA, not available. 
Table 2 Patients' last clinical and biological evaluations.

\begin{tabular}{|c|c|c|c|c|c|c|c|c|c|c|}
\hline \multirow[b]{2}{*}{ Patient } & \multicolumn{3}{|c|}{ Test. treatment during infancy } & \multirow[b]{2}{*}{$\begin{array}{c}\text { Age at } \\
\text { last CE } \\
\text { (years) }\end{array}$} & \multirow[b]{2}{*}{$\begin{array}{l}\text { Penile } \\
\text { length } \\
(\mathrm{mm})\end{array}$} & \multirow[b]{2}{*}{$\begin{array}{l}\text { Testes size } \\
\text { (right/left, mm) }\end{array}$} & \multirow[b]{2}{*}{$\begin{array}{c}\text { Age at } \\
\text { last BA } \\
\text { (years) }\end{array}$} & \multirow[b]{2}{*}{$\begin{array}{l}\text { Test. } \\
(\mathrm{ng} / \mathrm{ml})\end{array}$} & \multirow[b]{2}{*}{$\begin{array}{c}\text { Inhibin B } \\
(\mathrm{pg} / \mathrm{ml})\end{array}$} & \multirow[b]{2}{*}{$\begin{array}{c}\text { LH/FSH } \\
(I U / I)\end{array}$} \\
\hline & Dose (mg) & $\begin{array}{l}\text { Time } \\
\text { given } \\
(\mathrm{mm})\end{array}$ & $\begin{array}{l}\text { Increase in } \\
\text { penile } \\
\text { length }\end{array}$ & & & & & & & \\
\hline 1 & & & & 54 & 100 & No testis & - & i.m. & & \\
\hline 2 & & & & 43 & 70 & Bilateral prosthesis & - & i.m. & & \\
\hline 3 & & & & 24 & 30 & No testis & - & i.m. & & \\
\hline 4 & & & & 17 & 75 & $35 / 0$ & 15 & 5.9 & & $? / 14.7$ \\
\hline 5 & $7 \times 30$ & M6-M13 & +15 & 16 & 100 & $0 / 40$ & - & - & & \\
\hline 6 & $3 \times 25$ & Y3 & +5 & 17 & & $35 / 35$ & 17 & 4 & & $4.2 / 6.6$ \\
\hline 7 & & & & & & & - & - & & \\
\hline 8 & - & & & 17 & & $35 / 0$ & 17 & 6 & $<15$ & $9.8 / 26$ \\
\hline 9 & $3 \times 25$ & Before $\mathrm{Y} 1$ & +20 & 15 & & $30 / 0$ & 15 & 2 & & $4.4 / 25.6$ \\
\hline 10 & $7 \times 30$ & Before Y1 & & 15 & 50 & $50 / 0$ & 15 & 3.3 & & $4.9 / 11$ \\
\hline 11 & & & & 18 & 80 & Bilateral prosthesis & 17 & - & $<6$ & $10 / 46$ \\
\hline 12 & & & & 18 & 50 & $25 / 40$ & 18 & i.m. & & $9.1 / 30.8$ \\
\hline 13 & & & & 18 & & $40 / 0$ & 18 & 7.4 & & $1.7 / 7.6$ \\
\hline 14 & $8 \times 25$ & M2-M7 & & 17.5 & 80 & Prosthesis/25 & 17.5 & i.m. & $<10$ & $4.8 / 14$ \\
\hline 15 & & & & 17 & 60 & $45 / 35$ & 15.5 & i.m. & $<10$ & $1.9 / 19$ \\
\hline 16 & & & & 16 & 60 & $40 / 40$ & 16 & 2.7 & 18 & $9 / 15$ \\
\hline 17 & $6 \times 25$ & Y2 & & 16 & 80 & $35 / 0$ & 15 & 3.4 & & $3.3 / 2$ \\
\hline 18 & & & & 16 & 105 & $40 / 0$ & 16.5 & i.m. & 41 & $0.2 / 0.8$ \\
\hline 19 & $6 \times 30$ & M1-M4 & +11 & 14 & 60 & $40 / 0$ & 14 & 1.5 & 77 & $2.1 / 5.2$ \\
\hline 20 & $3 \times 50$ & M8-M10 & & 13.5 & 40 & $0 / 25$ & 13 & 0.7 & 66 & $2.9 / 8.7$ \\
\hline
\end{tabular}

$\mathrm{M}$, month; $\mathrm{Y}$, year; $\mathrm{CE}$, clinical evaluation; BA, biological analyses; test., testosterone; i.m., patient on intramuscular testosterone treatment at the time of biological analysis.

gonadectomy was performed at a mean age of $5.8 \pm 1.5$ years. Eleven boys $(55 \%)$ were gonadectomized on the streak gonad side. Four patients $(20 \%)$ were gonadectomized on both sides because of testicular cancer or profound testicular dysfunction.

\section{Puberty}

In 17 of the $20(85 \%)$ boys puberty initiated spontaneously at a mean age of $12.7 \pm 0.3$ years (10.8-14.4; Table 3) while three (15\%; nos 2, 11, and 14) displayed signs of impaired testicular function and required hormonal treatment to initiate puberty. Testosterone therapy had to be added subsequently in six patients (nos 1, 3, 12, 15, 18, and 20) for the completion of puberty. No difference in phenotypic presentation at birth was observed between patients requiring hormonal treatment to induce puberty and those that did not. Interestingly, as seen in the Supplementary Table 2 (see section on supplementary data given at the end of this article) patients 9, 11, 12, and 14 had normal hormonal levels during the neonatal period, which did not preclude from later testicular dysfunction.

Mean adult penile length was $72 \pm 6(30-105) \mathrm{mm}$. It measured $<80 \mathrm{~mm}$ long $(-2 \mathrm{SDS}$ of the general population (18)) in $7 / 13(54 \%)$ patients (Table 2). No relationship was found between adult penile length and either testosterone treatment before or during puberty $(P=0.72$ and 0.37 respectively) or with genital tubercle length at birth $(P=0.71)$.

\section{Adult height}

Thirteen boys (65\%) received recombinant GH therapy at a mean age of $9.8 \pm 1.1(5-14.7)$ years, during $6.5 \pm 1.4(0.6-12.8)$ years (Table 3$)$, and at a mean dose of $0.03(0.025-0.035) \mathrm{mg} / \mathrm{kg}$ per day.

Thirteen patients, older than 17 years at their last height evaluation (after at least a 3-year-long puberty), were evaluated for pubertal growth spurt and near-adult height. Mean pubertal growth spurt was $12.3 \pm 1.3$ $(7.2-21.7) \mathrm{cm}$. Mean adult height was $156.9 \pm 2$ (146-171) cm, equivalent to -3 SDS (Table 3). Mean height loss was $16.2 \pm 1.1(12.5-23.8) \mathrm{cm}$ in comparison to predicted adult height based on parental height (data not shown). No difference was observed between children treated with $\mathrm{GH}$ and those left untreated $(157 \pm 2.3$ vs $156.6 \pm 4.2 \mathrm{~cm}$, respectively, $P=0.83$; Table 3).

Final height was also independent of the presence or absence of IUGR at birth $(P=0.82)$, and no difference was seen between children with spontaneous vs induced puberty $(P=0.9)$.

\section{Fertility}

No patient has had children to date. Of the 20 patients, nine $(45 \%)$ developed testicular insufficiency requiring testosterone therapy. Among others, 6/9 (67\%) patients had signs of impaired testicular function at the end of puberty (increased levels of FSH and low levels of testosterone and/or inhibin B; Table 2). 
Table 3 Growth and pubertal development. Age at last height evaluation is specified when measured during puberty (these patients were not taken into account for mean final stature). Pubertal growth spurt corresponds to the total height gain throughout puberty.

\begin{tabular}{|c|c|c|c|c|c|c|c|}
\hline Patient & $\begin{array}{l}\text { GH } \\
\text { therapy }\end{array}$ & $\begin{array}{c}\text { Age at onset } \\
\text { of treatment } \\
\text { (years) }\end{array}$ & $\begin{array}{c}\text { Duration of } \\
\text { GH therapy } \\
\text { (years) }\end{array}$ & $\begin{array}{l}\text { Spontaneous } \\
\text { puberty and } \\
\text { age (years) }\end{array}$ & $\begin{array}{l}\text { Age at onset of } \\
\text { testosterone } \\
\text { therapy (years) }\end{array}$ & $\begin{array}{c}\text { Pubertal } \\
\text { growth spurt } \\
(\mathrm{cm})\end{array}$ & Final stature $(\mathrm{cm} / \mathrm{SDS})$ \\
\hline 1 & - & & & Yes, 12 & 13 & & $154 /-3.5$ \\
\hline 2 & - & & & No & 13 & 15.5 & $146 /<-4$ \\
\hline 3 & - & & & Yes, - & 24 & 15 & $152 /-3.8$ \\
\hline 4 & Yes & 14.4 & 0.6 & Yes, 13.8 & & 7.2 & $150.2 /-4$ \\
\hline 5 & Yes & 10.3 & 3.4 & Yes, 12.8 & & & 151.5 (16 years)/-3 \\
\hline 6 & Yes & 13.4 & 3.7 & Yes, 14.4 & & 7.6 & $152.4 /-3.7$ \\
\hline 7 & Yes & 7 & 10.3 & Yes, - & & & $161.5 /-2.2$ \\
\hline 8 & Yes & 14.7 & 2.4 & Yes, 14 & & 12 & $155.3 /-3.2$ \\
\hline 9 & Yes & 5.3 & 9.7 & Yes, 10.8 & & 13 & 139 (15 years)/ -3.5 \\
\hline 10 & Yes & 11.6 & 1.3 & Yes, 11 & & 10.5 & $150 /-4$ \\
\hline 11 & Yes & 14.4 & & No & 16.7 & 10 & $157.5 /-3$ \\
\hline 12 & Yes & 5 & 12.8 & Yes, 13.3 & 14.3 & 21.7 & $160.7 /-2.4$ \\
\hline 13 & - & & & Yes, 13.5 & & 11.5 & $160 /-2.5$ \\
\hline 14 & Yes & 10 & 5.6 & No & 13.3 & 12 & $168.5 /-1$ \\
\hline 15 & - & & & Yes, - & 14.8 & & $171 /-0.7$ \\
\hline 16 & Yes & 4.2 & 11.6 & Yes, 13 & & 14 & $156(15$ years $) /-1.5$ \\
\hline 17 & - & & & Yes, 12.4 & & & \\
\hline 18 & Yes & 12.3 & & Yes, 12.3 & 14.5 & 28.5 & $162(16$ years $) /-1.5$ \\
\hline 19 & Yes & 5 & 10 & Yes, 12.7 & & & 150 (14 years)/-1.2 \\
\hline 20 & - & & & Yes, 12.3 & 13 & & 150 (13.5 years $) /-0.8$ \\
\hline
\end{tabular}

\section{Quality of life}

Only limited data were obtained. Questionnaires were given or sent to the patients in order to evaluate data concerning their quality of life. Fourteen of them returned the questionnaire. Only $50 \%$ of them were satisfied by their physical appearance. The principal cause of dissatisfaction was the short stature. Only six patients answered the question concerning their sexual life, which could reflect a negative psychosocial outcome. Four of these six patients were older than 20 years $(27,45,47$, and 58 years). Two patients had no sexual life (45 and 47 years) and two were satisfied by their sexual life ( 27 and 58 years).

None of these patients had asked for gender reorientation.

\section{Cytogenetic analyses}

Karyotypes The percentage of 45,X cells in peripheral blood karyotypes varied from 6 to $91 \%$ (Table 1). No correlation was found between neonatal phenotype, adult height, pubertal development or the presence of other pathologies, and the degree of mosaicism in peripheral blood leukocytes.

Structural anomalies Karyotype analyses revealed a $\mathrm{Y}$ chromosome rearrangement in 10/16 (63\%) patients: deletion in five, isochromosome in two, isodicentric chromosome in two, or ring chromosome in one. For the majority, these rearrangements resulted in loss of all or part of the long arm of the Y chromosome, which contains several major genes required for normal spermatogenesis $(19,20)$. No correlation was found between the type of Y chromosome rearrangement and the neonatal phenotype, as previously reported (12).

\section{Discussion}

This study reports the first long-term retrospective observational study of 45,X/46,XY patients born with ambiguous genitalia and raised as boys. These patients presented a classical phenotype of MGD at birth in $85 \%$ of the cases. The phenotype was independent of the percentage of 45 , X cells in lymphocyte karyotype, as already reported $(5,7)$. All patients had an impaired secretion of testosterone and AMH during fetal life, as assessed by the presentation of internal and external genitalia at birth, which could suggest a decreased androgenization of the whole fetus. Sex assignment was decided in the neonatal period in accordance with the parents, based more on the clinicians' experience than on the child's phenotype.

Pubertal onset, hormonal requirement for impaired testicular secretion, and final adult height were not related to neonatal phenotype or hormonal levels during infancy. These results demonstrate that the degree of androgenization in the fetal/neonatal period could not predict pubertal and fertility outcome in the patients of our study. Indeed, patient no. 16, who had two scrotal testes at birth, was able to spontaneously induce his puberty at 13 years; however, he was only $156 \mathrm{~cm}$ tall and displayed functional signs of testicular impairment at 16 years (FSH, $15 \mathrm{UI} / \mathrm{l}$; inhibin B, $18 \mathrm{pg} / \mathrm{ml}$; and testosterone, $2.7 \mathrm{ng} / \mathrm{ml}$ ). Similarly, 
patients who initiated puberty spontaneously have had equivalent final stature and penile length compared with those who required hormonal substitution, which suggests that all have, in reality, two dysfunctional gonads. Intriguingly, no relationship was found between testosterone therapy and final penile length, as previously reported (11). Testosterone doses were similar to recommendations (21). However, in the general population, the highest penile length velocity is associated with increased levels of testosterone during the first 3 months after birth (22). This finding supports the concept of a specific male programming window that determines final penile size, similar to the results found in rodents (23). Thus, a delayed initiation of testosterone treatment in the patients of our study could explain adult penile length. Another hypothesis could be a variable length of the CAG repeats in exon 1 of the androgen receptor gene, which can modify hormone responsiveness and influence penile length in Klinefelter syndrome (24) as well as in normal 46,XY males (25).

One of the most relevant results of our study was the short final stature, with $62 \%$ of the patients measuring $<160 \mathrm{~cm}(<-2$ SDS), independent of IUGR, testosterone treatment, or GH treatment. Patients treated by GH and those left untreated reach similar final stature. Short final stature associated with a reduced pubertal growth spurt is most certainly related to the $45, \mathrm{X}$ cell clone in these patients, by haploinsufficiency of the SHOX gene $(26,27)$. This cellular clone also accounts for IUGR. Therefore, clinical management could be compared with that of TS. Interestingly, our results are slightly different from those obtained in TS cohort studies (28). However, these reports do not take into account $45, \mathrm{X} / 46, \mathrm{XY}$ patients, who, in fact, reach a final stature, with or without GH, higher than TS patients treated with GH. Nevertheless, the use of higher GH doses (29), initiated earlier in life (62\% of our patients started GH therapy after 9 years of age, with significant correlation between final height and duration of hormonal treatment $(P=0.05))(30)$ and adjusted to insulin-like growth factor 1 levels (31), might improve these results. Therefore, prospective randomized studies of GH effect in this population of patients should be encouraged.

Fertility is also an important part of a clinician's decision of sex assignment. It was thought that a completely descended testis, implying a normal homolateral testosterone secretion during fetal life, could be compatible with normal adult fertility. Unfortunately, our results suggest that the majority of mixed gonadal dysgenetic patients born with ambiguous genitalia are infertile. Indeed, $45 \%$ of them undergo testosterone treatment in adulthood, and most of the others have signs of declined testicular function, which has also been reported by Kojima et al. (11). No patient has had children to date. Moreover, the high frequency of $\mathrm{Y}$ chromosome rearrangements observed in our patients $(63 \%)$, resulting most frequently in Yq loss, is known to alter fertility $(19,20,32)$. Finally, the risk for malignant testicular cancer, which reached $10 \%$ in our patients and could develop from an apparently 'normal' testis, underlines the necessity for strict surveillance of gonads that need to be removed in case of signs of testicular impairment (low testosterone levels and/or low inhibin B levels, high LH and FSH levels). This result corroborates previous studies $(33,34)$. As a consequence, the decision of raising a mixed gonadal dysgenetic patient as male cannot be based on a hypothetical fertility potential. Moreover, several publications have demonstrated that impaired fertility and short stature, each considered individually, are responsible for negative psychosocial outcomes in adult men $(35,36,37)$.

Patients also presented various organ anomalies, similar to those observed in TS, as previously reported by Telvi et al. (5). These anomalies are related to the $45, \mathrm{X}$ cell line (38). Interestingly, no correlation was observed between the percentage of $45, \mathrm{X}$ cells evaluated in leukocytes and the severity of ambiguous genitalia at birth, final height, or the presence of a renal or cardiac malformation. This implies that patients who have the highest percentage of 45 , $X$ cells in a blood sample are not necessarily the ones with renal malformation or the shortest stature, and vice versa. Therefore, the percentage of $45, \mathrm{X}$ cells varies from one organ to the other. These results underline that phenotypicly normal males, with a 45,X/46,XY karyotype, may have dysfunctional organs (kidney, heart, etc.), final short stature $(39,40)$, delayed puberty (41), and be infertile (13).

Finally, our study gives credit to the theory, based on chromosome instability, of a link between a Y chromosome rearrangement that may predispose to anaphase lag and emergence of a 45,X cell line, and the occurrence of a disorder of sexual development, which has been proposed by other authors $(5,12,14,15,16,17)$. Indeed, $63 \%$ of our patients had abnormal Y chromosome structure, which is higher than that found in $45, \mathrm{X} / 46, \mathrm{XY}$ patients considering all phenotypes $(20 \%)$ (10). As prenatal diagnosis of $45, \mathrm{X} / 46, \mathrm{XY}$ mosaicism usually gives rise to a genetic counseling dilemma, the detection of a Y structural rearrangement could indicate higher risk for ambiguous genitalia and infertility. The use of unbiased data from prenatally diagnosed cases should be encouraged in order to highlight this hypothesis.

\section{Conclusion}

From this study, it appears that $45, \mathrm{X} / 46, \mathrm{XY}$ children born with ambiguous genitalia and raised as boys have an altered pubertal course, a final short stature, and impaired fertility, which should therefore be taken into consideration when assigning gender at birth and determining the most appropriate course of treatment. 


\section{Supplementary data}

This is linked to the online version of the paper at http://dx.doi.org/10. 1530/EJE-11-0756.

\section{Declaration of interest}

The authors (L Martinerie, Y Morel, C-L Gay, C Pienkowski, $\mathrm{M}$ de Kerdanet, S Cabrol, C Lecointre, R Coutant, S Baron, M Colle, R Brauner, E Thibaud, J Leger, C Nihoul-Fekete, and C Bouvattier) declare that there is no conflict of interest that could be perceived as prejudicing the impartiality of the research reported.

\section{Funding}

This research did not receive any specific grant from any funding agency in the public, commercial or not-for-profit sector.

\section{References}

1 Meyer-Bahlburg HF, Dolezal C, Baker SW, Ehrhardt AA \& New MI. Gender development in women with congenital adrenal hyperplasia as a function of disorder severity. Archives of Sexual Behavior 200635 667-684. (doi:10.1007/s10508-006-9068-9)

2 Migeon CJ, Wisniewski AB, Gearhart JP, Meyer-Bahlburg HF, Rock JA, Brown TR, Casella SJ, Maret A, Ngai KM, Money J \& Berkovitz GD. Ambiguous genitalia with perineoscrotal hypospadias in 46,XY individuals: long-term medical, surgical, and psychosexual outcome. Pediatrics 2002110 e31. (doi:10.1542/ peds.110.3.e31)

3 Migeon CJ, Wisniewski AB, Brown TR, Rock JA, MeyerBahlburg HF, Money J \& Berkovitz GD. 46,XY intersex individuals: phenotypic and etiologic classification, knowledge of condition, and satisfaction with knowledge in adulthood. Pediatrics 2002 110 e32. (doi:10.1542/peds.110.3.e32)

4 Chang HJ, Clark RD \& Bachman H. The phenotype of 45,X/46,XY mosaicism: an analysis of 92 prenatally diagnosed cases. American Journal of Human Genetics 199046 156-167.

5 Telvi L, Lebbar A, Del Pino O, Barbet JP \& Chaussain JL. 45,X/46,XY mosaicism: report of 27 cases. Pediatrics 1999104 304-308. (doi:10.1542/peds.104.2.304)

6 Rosenberg C, Frota-Pessoa O, Vianna-Morgante AM \& Chu TH. Phenotypic spectrum of $45, \mathrm{X} / 46, \mathrm{XY}$ individuals. American Journal of Medical Genetics 198727 553-559. (doi:10.1002/ ajmg.1320270308)

7 Mendez JP, Ulloa-Aguirre A, Kofman-Alfaro S, Mutchinick O, Fernandez-del-Castillo C, Reyes E \& Perez-Palacios G. Mixed gonadal dysgenesis: clinical, cytogenetic, endocrinological, and histopathological findings in 16 patients. American Journal of Medical Genetics 199346 263-267. (doi:10.1002/ajmg.132 0460304)

8 Knudtzon J \& Aarskog D. 45,X/46,XY mosaicism. A clinical review and report of ten cases. European Journal of Pediatrics 1987146 266-271. (doi:10.1007/BF00716471)

9 Ayuso MC, Ramos MC, Bello MC, Jimenez A, Sanchez Cascos A \& Herrera JL. Cytogenetic and clinical findings in ten 45,X/46,XY patients. Clinical Genetics 198425 336-340. (doi:10.1111/ j.1399-0004.1984.tb02000.x)

10 Gantt PA, Byrd JR, Greenblatt RB \& McDonough PG. A clinical and cytogenetic study of fifteen patients with $45, \mathrm{X} / 46 \mathrm{XY}$ gonadal dysgenesis. Fertility and Sterility 198034 216-221.

11 Kojima Y, Mizuno K, Nakane A, Kato T, Kohri K \& Hayashi Y. Long-term physical, hormonal, and sexual outcome of males with disorders of sex development. Journal of Pediatric Surgery 200944 1491-1496. (doi:10.1016/j.jpedsurg.2008.10.111)
12 Hsu LY. Phenotype/karyotype correlations of Y chromosome aneuploidy with emphasis on structural aberrations in postnatally diagnosed cases. American Journal of Medical Genetics 199453 108-140. (doi:10.1002/ajmg.1320530204)

13 Penna Videau S, Araujo H, Ballesta F, Ballesca JL \& Vanrell JA. Chromosomal abnormalities and polymorphisms in infertile men. Archives of Andrology 200146 205-210. (doi:10.1080/0148 5010151096504)

14 Siffroi JP, Le Bourhis C, Krausz C, Barbaux S, Quintana-Murci L, Kanafani S, Rouba H, Bujan L, Bourrouillou G, Seifer I, Boucher D, Fellous M, McElreavey K \& Dadoune JP. Sex chromosome mosaicism in males carrying Y chromosome long arm deletions. Human Reproduction 200015 2559-2562. (doi:10.1093/humrep/15.12.2559)

15 Lange J, Skaletsky H, van Daalen SK, Embry SL, Korver CM, Brown LG, Oates RD, Silber S, Repping S \& Page DC. Isodicentric Y chromosomes and sex disorders as byproducts of homologous recombination that maintains palindromes. Cell 2009138 855-869. (doi:10.1016/j.cell.2009.07.042)

16 Ravel C \& Siffroi JP. Y chromosome structural abnormalities and Turner's syndrome. Gynécologie, Obstétrique \& Fertilité 200937 511-518. (doi:10.1016/j.gyobfe.2009.04.018)

17 Alvarez-Nava F, Puerta H, Soto M, Pineda L \& Temponi A. High incidence of Y-chromosome microdeletions in gonadal tissues from patients with 45,X/46,XY gonadal dysgenesis. Fertility and Sterility $2008 \mathbf{8 9}$ 458-460. (doi:10.1016/j.fertnstert.2007. 02.058)

18 Schonfeld WA. Primary and secondary sexual characteristics: study of their development in males from birth through maturity, with biometric study of penis and testes. American Journal of Diseases of Children 194365535.

19 Tiepolo L \& Zuffardi O. Localization of factors controlling spermatogenesis in the nonfluorescent portion of the human Y chromosome long arm. Human Genetics $1976 \mathbf{3 4}$ 119-124. (doi:10.1007/BF00278879)

20 Vogt PH, Edelmann A, Kirsch S, Henegariu O, Hirschmann P, Kiesewetter F, Kohn FM, Schill WB, Farah S, Ramos C, Hartmann M, Hartschuh W, Meschede D, Behre HM, Castel A, Nieschlag E, Weidner W, Grone HJ, Jung A, Engel W \& Haidl G. Human Y chromosome azoospermia factors (AZF) mapped to different subregions in Yq11. Human Molecular Genetics 19965 933-943. (doi:10.1093/hmg/5.7.933)

21 Tsang S. When size matters: a clinical review of pathological micropenis. Journal of Pediatric Health Care 201024 231-240. (doi:10.1016/j.pedhc.2009.05.001)

22 Boas M, Boisen KA, Virtanen HE, Kaleva M, Suomi AM, Schmidt IM, Damgaard IN, Kai CM, Chellakooty M, Skakkebaek NE, Toppari J \& Main KM. Postnatal penile length and growth rate correlate to serum testosterone levels: a longitudinal study of 1962 normal boys. European Journal of Endocrinology 2006154 125-129. (doi:10.1530/eje.1.02066)

23 Welsh M, Saunders PT, Fisken M, Scott HM, Hutchison GR, Smith LB \& Sharpe RM. Identification in rats of a programming window for reproductive tract masculinization, disruption of which leads to hypospadias and cryptorchidism. Journal of Clinical Investigation 2008118 1479-1490. (doi:10.1172/JCI34241)

24 Zinn AR, Ramos P, Elder FF, Kowal K, Samango-Sprouse C \& Ross JL. Androgen receptor CAGn repeat length influences phenotype of 47,XXY (Klinefelter) syndrome. Journal of Clinical Endocrinology and Metabolism 200590 5041-5046. (doi:10. $1210 /$ jc. 2005-0432)

25 Lim HN, Chen H, McBride S, Dunning AM, Nixon RM, Hughes IA \& Hawkins JR. Longer polyglutamine tracts in the androgen receptor are associated with moderate to severe undermasculinized genitalia in XY males. Human Molecular Genetics 20009 829-834. (doi:10.1093/hmg/9.5.829)

26 Rappold GA, Fukami M, Niesler B, Schiller S, Zumkeller W, Bettendorf M, Heinrich U, Vlachopapadoupoulou E, Reinehr T, Onigata K \& Ogata T. Deletions of the homeobox gene SHOX 
(short stature homeobox) are an important cause of growth failure in children with short stature. Journal of Clinical Endocrinology and Metabolism 200287 1402-1406. (doi:10.1210/jc.87.3.1402)

27 Haeusler G, Schemper M, Frisch H, Blumel P, Schmitt K \& Plochl E. Spontaneous growth in Turner syndrome: evidence for a minor pubertal growth spurt. European Journal of Pediatrics 1992151 283-287. (doi:10.1007/BF02072230)

28 Bryant J, Baxter L, Cave CB \& Milne R. Recombinant growth hormone for idiopathic short stature in children and adolescents. Cochrane Database of Systematic Reviews 200718 CD004440. (doi:10.1002/14651858)

29 van Pareren YK, de Muinck Keizer-Schrama SM, Stijnen T, Sas TC, Jansen M, Otten BJ, Hoorweg-Nijman JJ, Vulsma T, StokvisBrantsma WH, Rouwe CW, Reeser HM, Gerver WJ, Gosen JJ, Rongen-Westerlaken C \& Drop SL. Final height in girls with turner syndrome after long-term growth hormone treatment in three dosages and low dose estrogens. Journal of Clinical Endocrinology and Metabolism $2003 \mathbf{8 8}$ 1119-1125. (doi:10.1210/jc.2002021171)

30 Bechtold S, Dalla Pozza R, Schmidt H, Bonfig W \& Schwarz HP. Pubertal height gain in Ullrich-Turner syndrome. Journal of Pediatric Endocrinology \& Metabolism 200619 987-993. (doi:10.1515/ JPEM.2006.19.8.987)

31 Bondy CA. Care of girls and women with Turner syndrome: a guideline of the Turner Syndrome Study Group. Journal of Clinical Endocrinology and Metabolism 200792 10-25. (doi:10.1210/jc. 2006-1374)

32 Roberts KP. Y-chromosome deletions and male infertility: state of the art and clinical implications. Journal of Andrology 199819 255-259.

33 Lee PA, Houk CP, Ahmed SF \& Hughes IA. Consensus statement on management of intersex disorders. International Consensus Conference on Intersex. Pediatrics $2006 \mathbf{1 1 8}$ e488-e500. (doi:10.1542/peds.2006-0738)

34 Cools M, Pleskacova J, Stoop H, Hoebeke P, Van Laecke E, Drop SL, Lebl J, Oosterhuis JW, Looijenga LH \& Wolffenbuttel KP. Gonadal pathology and tumor risk in relation to clinical characteristics in patients with $45, \mathrm{X} / 46, \mathrm{XY}$ mosaicism. Journal of Clinical Endocrinology and Metabolism 201196 E1171-E1180. (doi:10.1210/ jc.2011-0232)
35 Bak CW, Seok HH, Song SH, Kim ES, Her YS \& Yoon TK. Hormonal imbalances and psychological scars left behind in infertile men. Journal of Andrology 2012 33. (doi:10.2164/jandrol.110.012351)

36 Cohen P, Rogol AD, Deal CL, Saenger P, Reiter EO, Ross JL, Chernausek SD, Savage MO \& Wit JM. Consensus statement on the diagnosis and treatment of children with idiopathic short stature: a summary of the Growth Hormone Research Society, the Lawson Wilkins Pediatric Endocrine Society, and the European Society for Paediatric Endocrinology Workshop. Journal of Clinical Endocrinology and Metabolism 200893 4210-4217. (doi:10.1210/jc. 2008-0509)

37 Klemetti R, Raitanen J, Sihvo S, Saarni S \& Koponen P. Infertility, mental disorders and well-being - a nationwide survey. Acta Obstetricia et Gynecologica Scandinavica 201089 677-682. (doi:10.3109/00016341003623746)

38 Rao E, Weiss B, Fukami M, Rump A, Niesler B, Mertz A, Muroya K, Binder G, Kirsch S, Winkelmann M, Nordsiek G, Heinrich U, Breuning MH, Ranke MB, Rosenthal A, Ogata T \& Rappold GA. Pseudoautosomal deletions encompassing a novel homeobox gene cause growth failure in idiopathic short stature and Turner syndrome. Nature Genetics 199716 54-63. (doi:10.1038/ ng0597-54)

39 Richter-Unruh A, Knauer-Fischer S, Kaspers S, Albrecht B, Gillessen-Kaesbach G \& Hauffa BP. Short stature in children with an apparently normal male phenotype can be caused by $45, \mathrm{X} / 46, \mathrm{XY}$ mosaicism and is susceptible to growth hormone treatment. European Journal of Pediatrics 2004163 251-256. (doi:10.1007/s00431-004-1406-0)

40 Tosson H, Rose SR \& Gartner LA. Children with 45,X/46,XY karyotype from birth to adult height. Hormone Research in Pediatrics 201074 190-200. (doi:10.1159/000281468)

41 Aranoff GS \& Morishima A. XO/XY mosaicism in delayed puberty. Journal of Adolescent Health Care 19889 501-504. (doi:10.1016/ S0197-0070(88)80011-1)

Received 26 August 2011

Revised version received 26 December 2011

Accepted 11 January 2012 